\title{
Allozyme variation in relation to ecotypic differentiation and population size in marginal populations of Silene nutans
}

\author{
FABIENNE VAN ROSSUM*, XAVIER VEKEMANS, PIERRE MEERTS, EMMANUELLE \\ GRATIA \& CLAUDE LEFËBVRE \\ Laboratoire de Génétique et Ecologie végétales, Université Libre de Bruxelles, Chaussée de Wavre, 1850, B-1160 \\ Brussels, Belgium
}

\begin{abstract}
In Belgium, at the north-western margin of its geographical range, Silene nutans is a rare species, which has evolved a silicicolous ( $\mathrm{Si}$ ) and a calcicolous (Ca) ecotype, with contrasting morphometric traits. Genetic diversity and population genetic structure were examined for seven allozyme loci in $16 \mathrm{Si}$ and $18 \mathrm{Ca}$ populations (a total of 567 individuals). High genetic variation was found at both the ecotypic and population level, and no significant correlation was found between population size and any measure of genetic variation. The maintenance of high levels of genetic diversity in small, marginal populations might be explained by the perennial, long-lived life form and the outcrossing breeding system of the species. Additionally, low $F_{\mathrm{ST}}$-values suggested that efficient gene flow was occurring within both ecotypes. Genetic distance measures and cluster analysis using UPGMA on the distance matrix revealed that the populations were differentiated according to their ecotypic property in two distinct gene pools. It is argued that the congruence of allozymic and morphometric differentiation between edaphic races is unusual for an outcrossing species. This finding, together with previous observations of isolating mechanisms between ecotypes, strongly suggests that incipient speciation is occurring within Silene nutans at the margin of its geographical range.
\end{abstract}

Keywords: allozyme, edaphic ecotype, marginal populations, population size, Silene nutans.

\section{Introduction}

Population genetics theory predicts that small, isolated populations will experience higher levels of genetic drift and lower levels of gene flow than large, interconnected populations (Barrett \& Kohn 1991; Ellstrand \& Elam, 1993). As a consequence, small populations are expected to show lower allelic diversity and heterozygosity within populations and higher genetic differentiation among populations than large populations (Lande, 1988; Hamrick \& Godt, 1989). Genetic erosion has recently been observed in populations of a few endangered plant species, which have become small and isolated owing to habitat destruction and fragmentation by human activities (Ouborg et al., 1991; Van Treuren et al., 1991; Raijmann et al., 1994).

Low levels of genetic variation can also be expected in marginal, disjunct populations of species

\footnotetext{
*Correspondence. E-mail: fvrossum@ulb.ac.be
}

with a wide geographical range (Soulé, 1973; Hoffmann \& Blows, 1994), as populations often become smaller, less frequent and sparsely distributed towards distribution limits (Wilson et al., 1991; Hoffmann \& Blows, 1994). Fragmented distributions can also reflect particular ecological requirements of the species, e.g. specific soils and/or climatic conditions (Linhart \& Premoli, 1994), and geographical marginality is often associated with ecologically marginal conditions (Wilson et al., 1991; Hoffmann \& Blows, 1994). In this context, genetic differentiation among marginal populations can arise either through the effect of drift, because of restricted gene flow and small population size, and/or through local adaptation.

In this paper, we investigate allozymic variation and population genetic structure in 34 marginal and disjunct populations of Silene nutans from Belgium. Silene nutans (Caryophyllaceae) is a diploid $(2 n=24)$, protandrous and predominantly outcrossed, herbaceous, long-lived perennial (Hepper, 1956; De Bilde, 
1973). It is a steppe species with a widespread Eurosiberian distribution range. In western Europe, at the border of its geographical range, it consists of marginal and disjunct populations (Hegi, 1979), occurring in xeric habitats (open grasslands and forest edges on rock outcrops), with a wide ecological range of substrates, and growing on both calcareous and siliceous bedrocks ( $\mathrm{pH}$ range 3.8-8.0) (De Bilde, 1978; F. Van Rossum, unpublished data). In Belgium, it is a rare species (Stieperaere \& Fransen,

Table 1 Genetic variation in 16 silicicolous and 18 calcicolous populations of Silene nutans

\begin{tabular}{|c|c|c|c|c|c|c|c|c|}
\hline Populations & $\mathrm{nb}$ & $N$ & $n$ & $A$ & $P$ & $H_{\mathrm{o}}$ & $H_{\mathrm{e}}$ & $F_{\text {IS }}$ \\
\hline \multicolumn{9}{|l|}{ Silicicolous ecotype } \\
\hline Treignes1 & 9 & 12 & 7 & 1.9 & 85.7 & 0.540 & 0.427 & -0.277 \\
\hline Treignes 2 & 10 & 13 & 11 & 2.1 & 85.7 & 0.389 & 0.377 & -0.042 \\
\hline Najauge & 11 & 18 & 10 & 2.4 & 85.7 & 0.398 & 0.451 & 0.033 \\
\hline Nonceveux & 15 & 27 & 10 & 2.3 & 85.7 & 0.317 & 0.359 & 0.069 \\
\hline Rouillon & 1 & 30 & 7 & 2.3 & 85.7 & 0.340 & 0.359 & 0.076 \\
\hline Ciergnon & 5 & 36 & 13 & 2.3 & 85.7 & 0.351 & 0.358 & -0.038 \\
\hline Vierves-sur-Viroin & 7 & 37 & 19 & 2.0 & 85.7 & 0.263 & 0.293 & 0.045 \\
\hline Vodelée† & 16 & 70 & 38 & 2.4 & 85.7 & 0.255 & 0.307 & 0.146 \\
\hline Houyet1 & 2 & 100 & 18 & 2.4 & 71.4 & 0.366 & 0.373 & 0.029 \\
\hline Houyet2 & 3 & 100 & 19 & 2.1 & 71.4 & 0.431 & 0.354 & -0.215 \\
\hline Lissoir & 4 & 100 & 13 & 1.7 & 71.4 & 0.307 & 0.285 & -0.078 \\
\hline Hamoir2 & 14 & 100 & 18 & 2.0 & 71.4 & 0.289 & 0.283 & -0.034 \\
\hline Tienne Moëssia & 8 & 130 & 23 & 2.7 & 85.7 & 0.414 & 0.510 & 0.138 \\
\hline Mont Vireux & 12 & 134 & 22 & 2.9 & 85.7 & 0.412 & 0.456 & 0.064 \\
\hline Olloy-sur-Viroin & 6 & 500 & 26 & 2.6 & 85.7 & 0.417 & 0.418 & -0.017 \\
\hline Hamoir1 & 13 & $>1000$ & 65 & 2.3 & 85.7 & 0.325 & 0.309 & -0.039 \\
\hline Mean & & & & 2.3 & 82.1 & 0.363 & 0.370 & -0.009 \\
\hline $\mathrm{SE}$ & & & & 0.08 & 1.6 & 0.018 & 0.017 & 0.028 \\
\hline \multicolumn{9}{|l|}{ Calcicolous ecotype } \\
\hline Tailfer1 & 18 & 5 & 4 & 2.1 & 71.4 & 0.410 & 0.365 & -0.137 \\
\hline Yvoir & 20 & 9 & 4 & 1.7 & 57.1 & 0.238 & 0.276 & 0.180 \\
\hline Bouvignes & 24 & 11 & 10 & 2.4 & 71.4 & 0.349 & 0.412 & 0.166 \\
\hline Tailfer 2 & 19 & 12 & 11 & 2.0 & 71.4 & 0.339 & 0.311 & -0.123 \\
\hline Oostduinkerke & 34 & 18 & 5 & 1.7 & 42.9 & 0.327 & 0.273 & -0.158 \\
\hline Dave & 17 & 25 & 15 & 2.4 & 71.4 & 0.416 & 0.364 & -0.137 \\
\hline Dinant2 & 22 & 27 & 13 & 2.1 & 71.4 & 0.281 & 0.370 & 0.186 \\
\hline Hastière-Lavaux & 25 & 30 & 12 & 2.1 & 71.4 & 0.321 & 0.383 & 0.116 \\
\hline Durbuy & 32 & 35 & 15 & 1.9 & 57.1 & 0.182 & 0.289 & 0.384 \\
\hline Herbet & 30 & 40 & 23 & 2.7 & 71.4 & 0.315 & 0.356 & 0.138 \\
\hline Chokier1 & 26 & 45 & 17 & 2.4 & 71.4 & 0.419 & 0.383 & -0.054 \\
\hline Sy & 29 & 47 & 12 & 2.0 & 71.4 & 0.297 & 0.312 & -0.021 \\
\hline Comblain-au-Pont & 28 & 50 & 12 & 2.4 & 71.4 & 0.361 & 0.396 & 0.111 \\
\hline Sosoye & 21 & 55 & 12 & 2.1 & 71.4 & 0.321 & 0.341 & -0.098 \\
\hline Mont-des-Pins & 31 & 70 & 28 & 2.7 & 71.4 & 0.371 & 0.377 & 0.007 \\
\hline Dinant 1 & 23 & 100 & 18 & 2.7 & 71.4 & 0.410 & 0.392 & -0.036 \\
\hline Chokier2 & 27 & 100 & 21 & 2.4 & 71.4 & 0.375 & 0.374 & -0.011 \\
\hline Sint-Idesbald & 33 & 100 & 16 & 2.1 & 57.1 & 0.340 & 0.308 & -0.106 \\
\hline Mean & & & & 2.2 & 67.4 & 0.337 & 0.349 & 0.023 \\
\hline $\mathrm{SE}$ & & & & 0.07 & 1.9 & 0.015 & 0.010 & 0.035 \\
\hline
\end{tabular}

nb, reference number; $N$, total number of individuals; $n$, sample size; $A$, mean number of alleles per locus; $P$, proportion of polymorphic loci; $H_{\mathrm{o}}$, observed heterozygosity; $H_{\mathrm{e}}$, expected heterozygosity; $F_{\mathrm{IS}}$, Wright's inbreeding coefficient; SE, standard error.

†Population originating from a limestone bedrock, but showing morphological traits typical of the silicicolous ecotype. 
1982), consisting of small to relatively large and scattered populations, with population sizes ranging from 1 to 1000 individuals, but mostly fewer than 100 individuals (Table 1). Populations in Belgium are divisible into two edaphic ecotypes restricted to soils derived from carbonate-rich (Ca ecotype) and carbonate-poor ( $\mathrm{Si}$ ecotype) rocks. The two ecotypes differ in a number of vegetative and reproductive traits. Among other differences, the $\mathrm{Si}$ ecotype is characterized by larger fruits containing fewer, bigger seeds than the Ca ecotype (De Bilde, 1973). This species, therefore, provides an interesting opportunity to study relationships between the pattern of allozyme variation and ecological specialization in marginal populations.

\section{Materials and methods}

\section{Populations studied and sampling procedure}

The locations of the 34 populations examined (16 silicicolous, 18 calcicolous) are given in Fig. 1. The populations were grouped according to bedrock type (calcareous or siliceous) and tabulated in ascending order of population size, ranging from 5 to 1000 individuals. For populations larger than 100 individuals, population size was estimated by counting subsamples and extrapolating to the total population area. Ecotypic category, determined from 12 morphological characters following De Bilde (1973), was consistent with bedrock type in all populations except Vodelée (16), which originated from a calcareous bedrock but displayed morphometric traits typical of the Siecotype.
A total of 567 individual plants (rosette cuttings) were sampled in 1992 and 1993. In small populations, all the individuals or as many plants as possible (some plants were out of reach because they grew on vertical rock faces) were sampled, whereas in larger populations a random sample was collected from the whole population area.

\section{Electrophoretic procedure}

The material used for isozyme electrophoresis was rosette leaves that were stored at $-70^{\circ} \mathrm{C}$ after cutting or after extraction [extraction buffer (3.5 $\mathrm{v} / \mathrm{w}): 0.08 \mathrm{M}$ Tris $\mathrm{pH} 7.5,2$ per cent $(\mathrm{w} / \mathrm{v})$ polyvinylpyrrolidone (MW 40000), 1 per cent (w/v) polyethyleneglycol $6000,5 \mathrm{~mm}$ dithiothreitol, 0.1 per cent $(\mathrm{v} / \mathrm{v})$ mercaptoethanol] and centrifugation $(13000 \mathrm{~g})$ for $10 \mathrm{~min}$. Electrophoresis was carried out on vertical 7.5 per cent polyacrylamide gels with a Trisglycine, $\mathrm{pH} 8.3$, buffer system. Staining recipes are available on request. Five enzyme systems revealed a clear pattern for genetic analyses: alcohol dehydrogenase $(A D H$, EC 1.1.1.1), glutamic-oxaloacetic transaminase (loci GOT-1 and -2, EC 2.6.1.1), phosphoglucomutase (PGM, EC 5.4.2.2), leucine aminopeptidase (LAP, EC 3.4.11.1), esterase (loci EST-1 and -2, EC 3.1.1.-). As $S$. nutans is a diploid species, Mendelian genetic interpretation of phenotypes was possible; Mendelian inheritance was confirmed in progeny assays (F. Van Rossum, unpublished data).

\section{Data analysis}

All analyses of genetic data were performed using GEN-SURVEY, a program in $C$ language written by

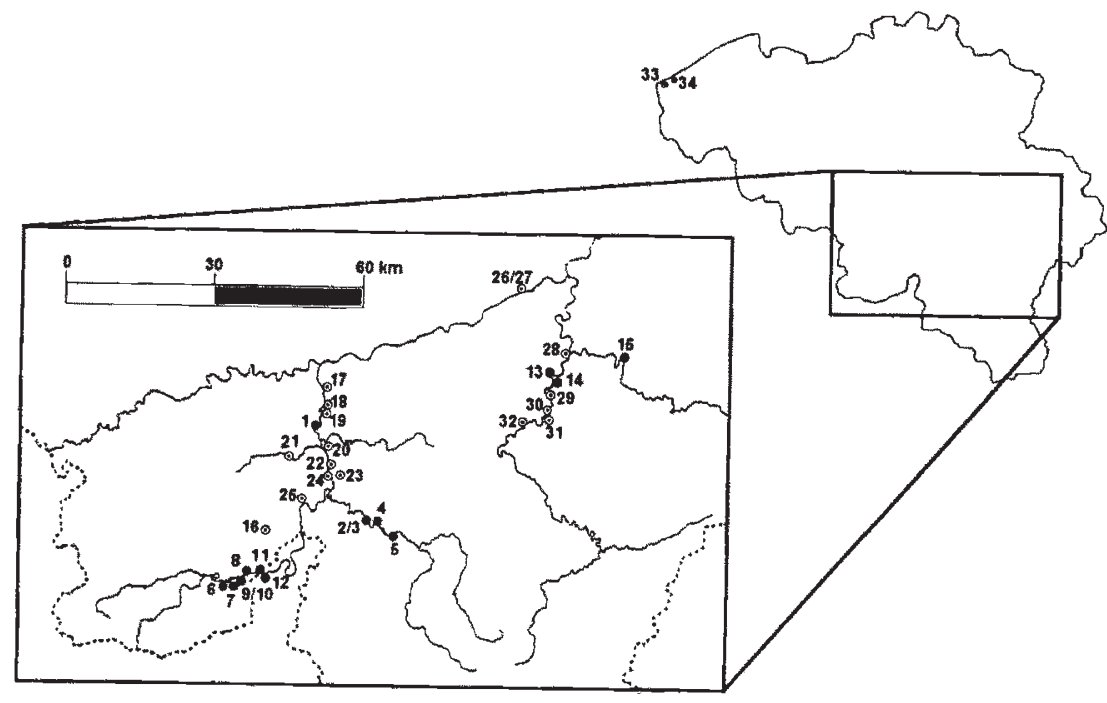

Fig. 1 Locations of the studied populations of Silene nutans in Belgium. Populations on siliceous bedrock; $\odot$, populations on calcareous bedrock. 
one of us (X. Vekemans and available on request), except when otherwise specified. The following measures of genetic variation were calculated for each population: the mean number of alleles per locus $(A)$, the proportion of polymorphic loci at the 5 per cent level $(P)$, the observed heterozygosity $\left(H_{\mathrm{o}}\right)$, the expected heterozygosity $\left(H_{\mathrm{e}}\right)$ corrected for small sample size (Nei, 1978), and Wright's inbreeding coefficient $\left(F_{\mathrm{IS}}\right)$ corrected for small sample size (Kirby, 1975). Correlation analysis was used to examine the relationships between population size $\left(\log _{10}\right.$-transformed data) and the different measures of genetic variation.

Genetic distances based on the coancestry coefficient, $\theta$, corrected for small sample size (Reynolds $e t$ $a l ., 1983)$ were calculated as $-\ln (1-\theta)$ for each pair of populations. A distance based on the coancestry coefficient was preferred over Nei's distance, because overall differentiation was low and assumed to have occurred through drift only (Weir, 1990). Cluster analysis using the unweighted pair groups means method (UPGMA) was performed on distance data using NTSYS-PC (version 1.8). Average distances were computed separately for pairwise comparisons within each ecotype and for comparisons between ecotypes. The statistical significance of the difference between the average distances within ecotypes was investigated using the following numerical resampling method (Sokal \& Rohlf, 1995): 1000 samples were simulated by randomly assigning populations to each ecotype in order to build the distribution of the statistic under interest, i.e. the difference between average pairwise distances within ecotypes, then the observed difference was tested against two-tailed critical values at 95 per cent and 99 per cent of the distribution. The same method was used to test the significance of the difference between the average distance within against the average distance between ecotypes, in order to test for differentiation between ecotypes. Differences in mean allelic frequencies between the two ecotypes were tested by performing a Student's $t$-test assuming unequal variance on arcsine-transformed data. The observed value of $t$ was tested against an ad hoc distribution of $t$ obtained through numerical resampling as described above.

Population genetic structure was investigated using Nei's genetic diversity analysis on polymorphic loci using corrections for small sample size according to Nei \& Chesser (1983). Averages and standard errors over loci were calculated together with 95 per cent confidence intervals obtained through bootstrapping over loci. To examine the relationship between population size and population genetic structure, populations were assigned to three partly arbitrary size classes: small $(N \leq 40)$, intermediate $(40<N<100)$ and large $(N \geq 100)$. Nei's genetic diversity analyses were performed separately for the three classes.

The average level of gene flow among populations was investigated using Wright's method (Wright, 1951), which estimates the average number of immigrants per generation per population, $\overline{N m}$, as $1 / 4\left(1 / F_{\mathrm{ST}}-1\right) . F_{\mathrm{ST}}$-values were computed according to Weir (1990).

\section{Results}

\section{Loci and alleles scored}

The five enzyme systems were encoded by seven putative loci. All enzymes migrated anodally. One locus (GOT-2) was monomorphic in all populations, whereas the other six were polymorphic in at least one population. The locus $A D H$ was monomorphic in all $\mathrm{Ca}$ populations, and polymorphic in all $\mathrm{Si}$ populations.

Twenty-four alleles were detected at the six polymorphic loci: $A D H$ (two alleles), GOT-1 (four alleles), $P G M$ (three alleles), $L A P$ (five alleles), EST-1 (four alleles) and EST-2 (six alleles). Four alleles at three loci ( $A D H, P G M$ and $L A P$ ) were restricted to $\mathrm{Si}$ populations and two alleles at two loci (GOT-1 and EST-2) to Ca populations.

\section{Genetic distance measures}

In order to decide whether populations from siliceous and calcareous bedrocks should be treated separately in the analyses, we first computed pairwise genetic distances among populations and then performed a cluster analysis. The dendrogram revealed that all populations but one were grouped according to their calcareous or siliceous locations (Fig. 2). Vodelée (16), although originating from a calcareous bedrock, was found in the Si cluster.

Interpopulation genetic distance values within each ecotype were low, with an average of 0.148 (range $0.000-0.485$ ) and 0.133 (range $0.000-0.414$ ) for $\mathrm{Si}$ and $\mathrm{Ca}$ populations, respectively. These values were not significantly different from each other as tested by a numerical resampling method (test not shown). In contrast, the genetic distance for between-ecotype population pairs, with an average of 0.300 (range $0.046-0.599$ ), was significantly higher than the average distance within ecotypes, as tested by the same method $(P<0.01)$. From the 24 alleles surveyed, nine alleles belonging to six loci did show 


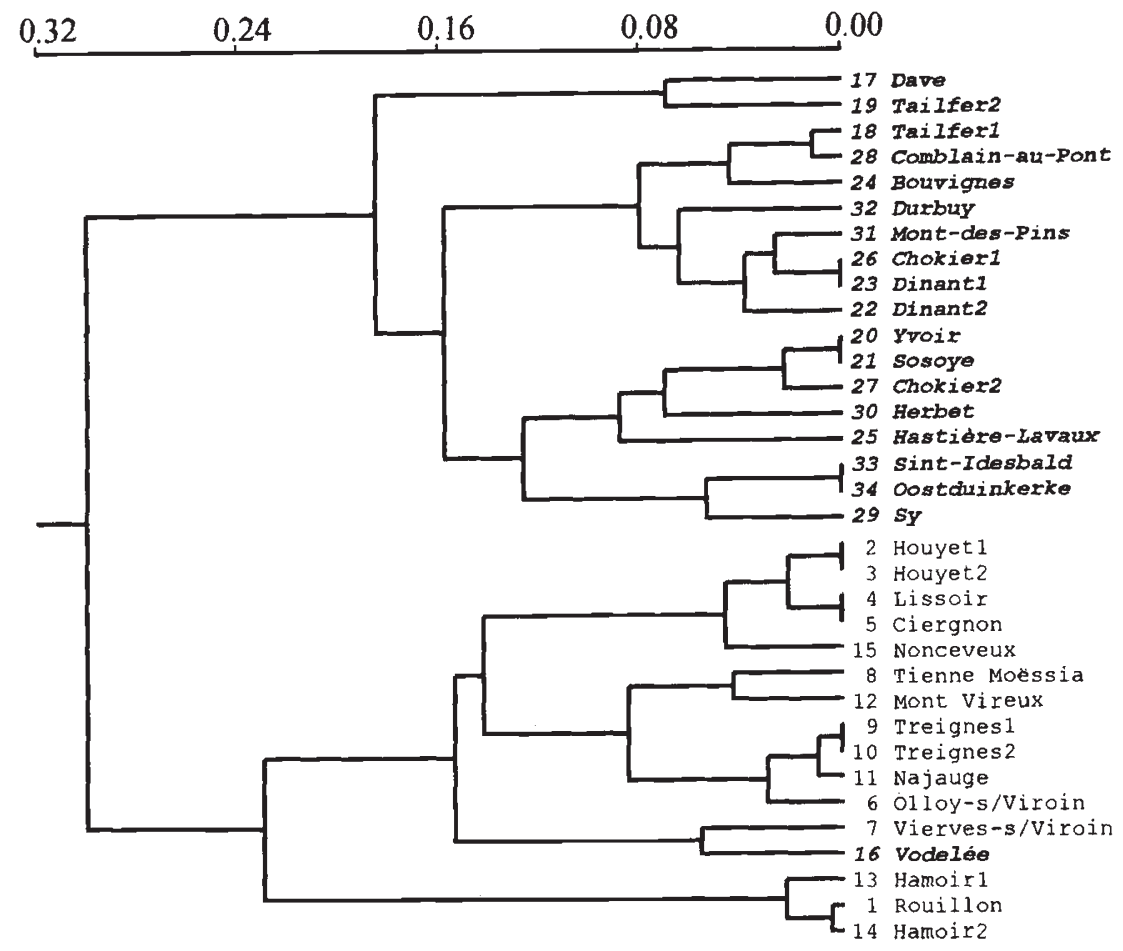

Fig. 2 Cluster analysis of silicicolous and calcicolous populations of Silene nutans based on Reynolds's genetic distance (Reynolds et al., 1983). Populations on calcareous bedrock are in italics. independent significant differences $(P<0.05)$ in frequency between $\mathrm{Ca}$ and $\mathrm{Si}$ populations. Accordingly, the subsequent analyses were conducted separately for each ecotype.

\section{Genetic variation within populations and population size}

The mean number of alleles per locus $(A)$ ranged from 1.7 to 2.9 for $\mathrm{Si}$ populations and from 1.7 to 2.7 for $\mathrm{Ca}$ populations, with mean values of 2.3 and 2.2 , respectively. The proportion of polymorphic loci $(P)$ ranged from 71.4 per cent to 85.7 per cent for $\mathrm{Si}$ populations and from 42.9 per cent to 71.4 per cent for $\mathrm{Ca}$ populations, with mean values of 82.1 per cent and 67.4 per cent, respectively (Table 1). The higher $P$-values of Si populations were mainly caused by an additional polymorphic locus $(A D H)$, which was monomorphic in all $\mathrm{Ca}$ populations.

Wright's inbreeding coefficient $\left(F_{\text {IS }}\right)$ values ranged from -0.277 to 0.146 for $\mathrm{Si}$ populations with a mean value of -0.009 , and from -0.158 to 0.384 for $\mathrm{Ca}$ populations with a mean value of 0.023 , indicating that no major trend of departure from Hardy-Weinberg genotypic frequencies was occurring.

No significant correlation was found between population size (log-scale) and $A, P, H_{\mathrm{o}}, H_{\mathrm{e}}$ and $F_{\mathrm{IS}}$ (Table 2) at either the species or the ecotypic level, with the exception of the mean number of alleles $(A)$ for $\mathrm{Ca}$ populations (positive correlation, $r=0.486, P<0.05)$. However, in order to test for the effect of unequal sample size (as sample size correlated positively with population size), we recalculated all the genetic measures from samples of equal size $(n=10)$ taken randomly in the original sample of each $\mathrm{Ca}$ population. No significant correlation was then found between population size and $A$.

\section{Population genetic structure and its relation to population size}

At the species level, averaged gene diversity values were: $H_{\mathrm{T}}=0.522, H_{\mathrm{S}}=0.419, D_{\mathrm{ST}}=0.103$ divided into $D_{\mathrm{SE}}$ (gene diversity among populations within ecotypes) $=0.059$ and $D_{\mathrm{ET}}$ (gene diversity among populations between ecotypes) $=0.044$ (Table 3). Hence, 8.4 per cent of the total genetic diversity could be accounted for by the variation between ecotypes, 11.3 per cent by variation among populations within ecotypes and 80.3 per cent by variation within populations.

$\mathrm{Ca}$ populations showed higher mean values of total and within-population gene diversity $\left(H_{\mathrm{T}}\right.$ and $H_{\mathrm{S}}$ ), although with overlapping 95 per cent confidence intervals, whereas mean values of gene diversity among populations $\left(D_{\mathrm{ST}}\right)$ and proportion of gene differentiation among population $\left(G_{\mathrm{ST}}\right)$ were similar 
for $\mathrm{Si}$ and $\mathrm{Ca}$ populations. For all loci combined, $G_{\mathrm{ST}}$ values were low $(<0.210)$, but different from zero (left-tailed critical value different from zero), indicating low genetic differentiation among populations in both ecotypes.

Three groups of populations (small, intermediate and large) were considered in order to analyse the relationships between population size and genetic structure (Table 3). For the Ca ecotype, the proportion of gene differentiation among populations $\left(G_{\mathrm{ST}}\right)$ decreased from 0.143 in small populations to 0.053 in large populations. However, the comparison

Table 2 Pearson's correlation coefficients between population size $(N, \log$ transformed) and the measures of genetic variation $\left(A, P, H_{\mathrm{o}}, H_{\mathrm{c}}\right.$ and $\left.F_{\mathrm{IS}}\right)$

\begin{tabular}{lcrrrr}
\hline $\log N$ & $A$ & \multicolumn{1}{c}{$P$} & \multicolumn{1}{c}{$H_{\mathrm{o}}$} & \multicolumn{1}{c}{$H_{\mathrm{e}}$} & \multicolumn{1}{c}{$F_{\mathrm{IS}}$} \\
\hline Ecotype & & & & & \\
Silicicolous & 0.347 & -0.192 & -0.164 & -0.110 & 0.124 \\
Calcicolous & $0.486^{*}$ & 0.140 & 0.134 & 0.202 & -0.036 \\
Silene nutans & $0.410^{*}$ & 0.230 & 0.028 & 0.062 & -0.004 \\
\hline
\end{tabular}

${ }^{*} P<0.05$. might be flawed by differences in the number of populations among the three groups (nine small, six intermediate and three large populations). In contrast, Si populations showed no difference in $G_{\text {ST }}$ in relation to population size $\left(G_{\mathrm{ST}}=0.113\right.$ and 0.108 for small and large populations, respectively).

The average level of gene flow among populations within each ecotype was estimated based on $F_{\mathrm{ST}}$ values. $\overline{N m}$, the mean number of immigrants per generation per population, was estimated as 1.75 for the Si ecotype and 1.89 for the Ca ecotype.

\section{Discussion}

\section{Overall levels of genetic variation and effect of population size}

Silene nutans shows considerable genetic variation when compared with the mean genetic diversity values given in Hamrick \& Godt (1989). The mean values of $A, P$ and $H_{\mathrm{e}}$ (Table 1 ) and the values of $H_{\mathrm{T}}$ and $H_{\mathrm{S}}$ at the ecotype level (Table 3 ) fall within the range of herbaceous long-lived perennials and of animal-pollinated species. Thus, the results do not support the hypothesis of low genetic diversity

Table 3 Measures of genetic diversity and substructuring for 16 silicicolous and 18 calcicolous populations of Silene nutans, at six and five polymorphic loci respectively

\begin{tabular}{|c|c|c|c|c|c|c|c|c|}
\hline \multirow[b]{2}{*}{ Locus } & \multicolumn{4}{|c|}{ Silicicolous ecotype } & \multicolumn{4}{|c|}{ Calcicolous ecotype } \\
\hline & $H_{\mathrm{T}}$ & $H_{\mathrm{S}}$ & $D_{\mathrm{ST}}$ & $G_{\mathrm{ST}}$ & $H_{\mathrm{T}}$ & $H_{\mathrm{s}}$ & $D_{\mathrm{ST}}$ & $G_{\text {ST }}$ \\
\hline$A D H \dagger$ & 0.459 & 0.420 & 0.039 & 0.084 & - & - & - & - \\
\hline GOT-1 & 0.401 & 0.319 & 0.083 & 0.206 & 0.516 & 0.423 & 0.093 & 0.180 \\
\hline$P G M$ & 0.509 & 0.465 & 0.044 & 0.086 & 0.483 & 0.483 & 0.000 & 0.000 \\
\hline$L A P$ & 0.468 & 0.446 & 0.022 & 0.047 & 0.641 & 0.559 & 0.082 & 0.128 \\
\hline EST-1 & 0.534 & 0.458 & 0.076 & 0.143 & 0.492 & 0.402 & 0.090 & 0.183 \\
\hline EST-2 & 0.597 & 0.486 & 0.111 & 0.186 & 0.650 & 0.587 & 0.063 & 0.096 \\
\hline Mean & 0.495 & 0.432 & 0.062 & 0.125 & 0.556 & 0.491 & 0.065 & 0.117 \\
\hline $\mathrm{SE}$ & 0.028 & 0.024 & 0.014 & 0.026 & 0.037 & 0.036 & 0.017 & 0.034 \\
\hline $95 \% \mathrm{CI}$ & $0.443-0.544$ & $0.378-0.468$ & $0.040-0.087$ & $0.082-0.173$ & $0.493-0.620$ & $0.431-0.555$ & $0.032-0.090$ & $0.054-0.171$ \\
\hline \multicolumn{9}{|l|}{ Populations } \\
\hline Small & 0.495 & 0.438 & 0.057 & 0.113 & 0.557 & 0.476 & 0.081 & 0.143 \\
\hline $95 \% \mathrm{CI}$ & $0.452-0.543$ & $0.406-0.475$ & & $0.080-0.139$ & $0.504-0.610$ & $0.416-0.536$ & $0.034-0.122$ & $0.058-0.224$ \\
\hline $\begin{array}{l}\text { Intermediate } \ddagger \\
95 \% \mathrm{CI}\end{array}$ & - & - & - & - & 0.560 & 0.509 & 0.052 & 0.090 \\
\hline $95 \% \mathrm{CI}$ & - & - & - & - & $0.499-0.629$ & $0.461-0.570$ & $0.026-0.077$ & $0.052-0.126$ \\
\hline $\begin{array}{l}\text { Large } \\
\quad 95 \% \mathrm{CI}\end{array}$ & 0.488 & 0.436 & 0.052 & 0.108 & 0.525 & 0.501 & 0.025 & 0.053 \\
\hline & $0.436-0.537$ & $0.371-0.485$ & $0.019-0.086$ & $0.037-0.190$ & $0.415-0.630$ & $0.387-0.610$ & $0.013-0.039$ & $0.022-0.092$ \\
\hline
\end{tabular}

$H_{\mathrm{T}}$, total gene diversity; $H_{\mathrm{S}}$, averaged gene diversity within populations; $D_{\mathrm{ST}}$, gene diversity among populations; $G_{\mathrm{ST}}$, proportion of interpopulation gene differentiation; $95 \% \mathrm{CI}$, ninety-five per cent confidence interval; SE, standard error. $\uparrow$ Monomorphic in Ca populations.

$\ddagger$ The only Si population in this group was not considered.

(c) The Genetical Society of Great Britain, Heredity, 78, 552-560. 
exhibited by marginally distributed populations (Soulé, 1973; Hoffman \& Blows, 1994). However, our results must be interpreted with caution because of the relatively low number of loci.

Population genetics theory predicts that, as a consequence of genetic drift, inbreeding and restricted gene flow, small populations should show lower levels of genetic variation and higher genetic differentiation among populations than large populations (Barrett \& Kohn, 1991; Ellstrand \& Elam, 1993). Genetic erosion in small populations was demonstrated for western European plants, including Salvia pratensis, Scabiosa columbaria (Van Treuren et al., 1991) and Gentiana pneumonanthe (Raijmann et al., 1994). Our data for $S$. nutans are not in agreement with these findings, as no major effect of population size on the extent and structure of genetic variation was detected. Similar results have been reported in small, disjunct populations of Gypsophila fastigiata (Prentice \& White, 1988) and Silene regia (Dolan, 1994). The maintenance of extensive genetic variation in spite of the scattered distribution and the small size of populations might be ascribed to particular life history traits (Hamrick et al., 1991). In S. nutans, a key trait is its long-lived perennial life form: all populations are deemed vigorous, even the smallest. Dispersal is assumed to be mainly by seeds (Hepper, 1956; Hegi, 1979). Secondly, $S$. nutans has a primarily outcrossing breeding system, being pollinated by moths (Hepper, 1956). Moreover, our data provide strong evidence that an efficient gene flow occurs among populations $(\overline{N m}>1)$, thereby counteracting genetic drift. In other rare species, high genetic diversity within populations was also explained by an outcrossing breeding system (Sampson et al., 1989; Dolan 1994; Richter et al., 1994), a long-lived perennial life form (Dolan 1994) or substantial gene flow (Sampson et al., 1989; Richter et al., 1994). Moreover, there is no indication that small populations of $S$. nutans have recently experienced a severe reduction owing to habitat destruction by human activities.

\section{Ecotypic differentiation}

The most striking result is the finding of a sharp differentiation for allozyme loci between $\mathrm{Ca}$ and $\mathrm{Si}$ populations, despite the fact that some $\mathrm{Si}$ populations are geographically intermixed with $\mathrm{Ca}$ populations. As the two ecotypes have evolved genetic adaptations to the mineral composition of their respective soils (De Bilde, 1978), we have evidence for correlated differences in allozymes and ecological traits in $S$. nutans.
Close associations between multilocus allozyme genotypes and ecological specialization have been commonly reported in selfing grasses and were found to occur at different ecological scales (Clegg \& Allard, 1972; Hamrick \& Allard, 1972; Nevo et al., 1988, 1994). Moreover, it was shown in Avena barbata that the allozyme differentiation was correlated with differences at a large proportion of the genome (Hamrick \& Allard, 1975). These observations were interpreted as evidence for selection acting on allozyme loci either directly or through genetic hitchhiking (Hamrick, 1989). However, investigations on allozyme frequency-environment correlations in outcrossing plant species have given contradictory results. Some authors reported significant correlations between habitat type and one or two allozyme loci (Heywood \& Levin, 1985 and two references cited therein). Conversely, several studies failed to show allozymic differentiation among ecological races (Westerbergh \& Saura, 1992; Freiley, 1993; Aitken \& Libby, 1994) and concluded, under the implicit assumption that allozyme loci are neutral, either that ecological separation was too recent for drift to have promoted allozymic divergence or that the latter had been prevented by sufficient gene flow. Similarly, studies comparing variation at allozyme loci with that at morphometric or other genetically controlled traits have not consistently shown an association among the different types of traits (Hamrick, 1989).

Our results on $S$. nutans, a predominantly outcrossed species (Hepper, 1956), show a significant association between nine alleles belonging to six loci and edaphic differentiation of $\mathrm{Ca}$ and $\mathrm{Si}$ populations. Referring to the work of $\mathrm{De}$ Bilde (1973) showing morphological differences between the same two ecotypes, there is thus a close association between allozymic and morphometric differentiation of these populations. It is noteworthy that the single exception to that association is the population of Vodelée (16), which breaks down the soilallozyme association but not the morphologyallozyme one. When compared with the data on outcrossing species in the literature reviewed above, the strong, multifarious differentiation of the two edaphic ecotypes of $S$. nutans is rather atypical. The results are more similar to comparisons between subspecies (van Dijk \& van Delden, 1981) or closely related species (Warwick \& Gottlieb, 1985) in which allozymic differentiation related to divergence in morphological and ecological traits has been observed. This raises the question of the phylogenetic origin of $\mathrm{Ca}$ and $\mathrm{Si}$ populations of $S$. nutans in Belgium. On the one hand, if the two groups of

(c) The Genetical Society of Great Britain, Heredity, 78, 552-560. 
populations are monophyletic with respect to each other, then the observed allozymic differences could result from the effect of genetic drift either before or after the colonization of Belgian sites. The allozymic differentiation between ecotypes could then have been maintained, without the effect of selection, because of the strong isolating barriers now existing between $\mathrm{Ca}$ and $\mathrm{Si}$ populations of $S$. nutans in Belgium (Van Rossum et al., 1996). On the other hand, if $\mathrm{Ca}$ and $\mathrm{Si}$ populations are polyphyletic with respect to each other, then disruptive selection on allozyme loci or linked loci must be invoked to explain the current pattern of differentiation. Currently, the origin of the two ecotypes is still unknown, so that the relative contributions of historical contingency and disruptive selection in the observed pattern of allozymic differentiation cannot be conclusively disentangled. Finally, the observation of high levels of gene flow within each ecotype, together with reproductive barriers and multifarious differentiation between them, suggests that the two edaphic ecotypes may effectively be different biological species.

\section{Acknowledgements}

We would like to thank $H$. van Dijk for comments on the manuscript, D. Parmentier for help with computation and an anonymous referee for constructive criticism. This study was financially supported by the Belgian National Fund for Scientific Research (F.N.R.S.) where F.V.R. is a research assistant.

\section{References}

AITKEN, S. N. AND LIBBY, w. J. 1994. Evolution of the pygmy-forest edaphic subspecies of Pinus contorta across an ecological staircase. Evolution, 48, 1009-1019.

BARRETT, s. C. H. AND KOHN, J. R. 1991. Genetic and evolutionary consequences of small population size. In: Falk, D. A. and Holsinger, K. E. (eds) Genetics and Conservation of Rare Plants, pp. 3-30. Oxford University Press, New York.

ClegG, M. T. AND ALlARD, R. w. 1972. Patterns of genetic differentiation in the slender wild oat species Avena barbata. Proc. Natl. Acad. Sci. U.S.A., 69, 1920-1924.

DE BILDE, J. 1973. Etude génécologique du Silene nutans L. en Belgique: populations du Silene nutans L. sur substrats siliceux et calcaires. Rev. Gén. Bot., 80, $161-176$.

DE BILDE, J. 1978. Nutrient adaptation in native and experimental calcicolous and silicicolous populations of Silene nutans. Oikos, 31, 383-391.

DOLAN, R. w. 1994. Patterns of isozyme variation in relation to population size, isolation, and phytogeographic history in royal catchfly (Silene regia; Caryophyllaceae). Am. J. Bot., 81, 965-972.

Ellstrand, N. C. AND ElaM, D. R. 1993. Population genetic consequences of small population size: implications for plant conservation. Ann. Rev. Ecol. Syst., 24, $217-242$.

FREILEY, K. J. 1993. Allozyme diversity and population genetic structure in Haplopappus gracilis (Compositae). Syst. Bot., 18, 543-550.

HAMRICK, J. L. 1989. Isozymes and analysis of genetic structure of plant populations. In: Soltis, D. and Soltis, P. (eds) Isozymes in Plant Biology, pp. 87-105. Dioscorides Press, Washington, DC.

HAMRICK, J. L. AND ALLARD, R. W. 1972. Microgeographical variation in allozyme frequencies in Avena barbata. Proc. Natl. Acad. Sci. U.S.A., 69, 2100-2104.

HAMRICK, J. L. AND AllaRd, R. w. 1975. Correlations between quantitative characters and enzyme genotypes in Avena barbata. Evolution, 29, 438-442.

HAMRICK, J. L. AND GODT, M. J. W. 1989. Allozyme diversity in plant species. In: Brown, A. H. D., Clegg, M. T., Kahler, A. L. and Weir, B. S. (eds) Plant Population Genetics, Breeding and Genetic Resources, pp. 43-63. Sinauer, Sunderland, MA.

HAMRICK, J. L., GODT, M. J. W., MURAWSKI, D. A. AND LOVELESS, M. D. 1991. Correlations between species traits and allozyme diversity: implications for conservation biology. In: Falk, D. A. and Holsinger, K. E. (eds) Genetics and Conservation of Rare Plants, pp. 75-86. Oxford University Press, New York.

HEGI, G. 1979. Illustrierte Flora von Mittel-Europa. Band III, Teil 2. Parey, Berlin.

HEPPER, F. N. 1956. Silene nutans L. Biological flora of the British Isles. J. Ecol., 44, 693-700.

HEYwOOD, J. S. AND LEVIN, D. A. 1985. Associations between allozyme frequencies and soil characteristics in Gaillardia pulchella (Compositae). Evolution, 39, 1076-1086.

HOFFMANN, A. A. AND Blows, M. w. 1994. Species borders: ecological and evolutionary perspectives. Trends Ecol. Evol., 9, 223-227.

KIRBY, G. C. 1975. Heterozygote frequencies in small subpopulations. Theor. Pop. Biol, , 8, 31-48.

LANDE, R. 1988. Genetics and demography in biological conservation. Science, 241, 1455-1460.

LINHART, Y. B. AND PREMOLI, A. C. 1994. Genetic variation in central and disjunct populations of Lilium parryi. Can. J. Bot., 72, 79-85.

NEI, M. 1978. Estimation of average heterozygosity and genetic distance from a small number of individuals. Genetics, 89, 583-590.

NEI, M. AND CHESSER, R. K. 1983. Estimation of fixation indices and diversities. Ann. Hum. Genet., 47, 253-259.

NEVO, E., BEILES, A. AND KRUGMAN, T. 1988. Natural selection of allozyme polymorphism: a microgeographical differentiation by edaphic, topographical and temporal factors in wild emmer wheat (Triticum dicoccoides). Theor. Appl. Genet., 76, 737-752. 
NEVo, E., KRUGMan, T. AND BEILES, A. 1994. Edaphic natural selection of allozyme polymorphisms in Aegilops peregrina at a Galilee microsite in Israel. Heredity, 72, 109-112.

OUBORG, N. J., VAN TREUREN, R. AND VAN DAMME, J. M. M. 1991. The significance of genetic erosion in the process of extinction. II. Morphological variation and fitness components in populations of varying size of Salvia pratensis L. and Scabiosa columbaria L. Oecologia, 86, 359-367.

PRENTICE, H. C. AND WHite, R. J. 1988. Variability, population size and isolation: the structuring of diversity in Öland Gypsophila fastigiata. Acta Oecol./Oecol. Plant., 9, 19-29.

RAIJMANN, L. E. L., VAN LEEUWEN, N. C., KERSTEN, R., OOSTERMEIJER, J. G. B., DEN NIJS, H. C. M. AND MENKEN, S. B. J. 1994. Genetic variation and outcrossing rate in relation to population size in Gentiana pneumonanthe L. Conserv. Biol., 8, 1014-1026.

REYNOLDS, J., WE1R, B. S. AND COCKERHAM, C. C. 1983. Estimation of coancestry coefficient: basis for a shortterm genetic distance. Genetics, 105, 767-779.

RiCHTER, T. S., SOLT1S, P. S. AND SOLT1S, D. E. 1994. Genetic variation within and among populations of the narrow endemic, Delphinium viridescens (Ranunculaceae). Am. J. Bot., 81, 1070-1076.

SAMPSON, J. F., HOPPER, S. D. AND JAMES, S. H. 1989. The mating system and population genetic structure in a bird-pollinated mallee, Eucalyptus rhodantha. Heredity, 63, 383-393.

SOKAL, R. R. AND ROHLF, F. J. 1995. Biometry: the Principles and Practice of Statistics in Biological Research, 3rd edn. W. H. Freeman, New York.
SOULÉ, M. 1973. The epistasis cycle: a theory of marginal populations. Ann. Rev. Ecol. Syst., 4, 165-187.

STIEPERAERE, H. AND FRANSEN, K. 1982. Standaardlijst van de Belgische vaatplanten, met aanduiding van hun zeldzaamheid en socio-oecologische groep. Dumortiera, 22, $1-41$.

VAN DIJK, H. AND VAN DELDEN, w. 1981. Genetic variability in Plantago species in relation to their ecology. 1. Genetic analysis of the allozyme variation in $P$. major subspecies. Theor. Appl. Genet., 60, 285-290.

VAN ROSSUM, F., DE BILDE, J. AND LEFÈBVRE, c. 1996. Barriers to hybridization in calcicolous and silicicolous populations of Silene nutans from Belgium. Belg. J. Bot., 129, (in press).

VAN TREUREN, R., BIJLSMA, R., OUBORG, N. J. AND VAN DELDEN, w. 1991. The significance of genetic erosion in the process of extinction. I. Genetic differentiation in Salvia pratensis and Scabiosa columbaria in relation to population size. Heredity, 66, 181-189.

WARWICK, s. 1. AND GOTTLIEB, L. D. 1985. Genetic divergence and geographic speciation in Layia (Compositae). Evolution, 39, 1239-1241.

WE1R, B. S. 1990. Genetic Data Analysis. Sinauer, Sunderland, MA.

WESTERBERGH, A. AND SAURA, A. 1992. The effect of serpentine on the population structure of Silene dioica (Caryophyllaceae). Evolution, 46, 1537-1548.

WILSON, J. B., RONGHUA, Y., MARK, A. F. AND AGNEW, A. D. Q. 1991. A test of the low marginal variance (LMV) theory, in Leptospermum scoparium (Myrtaceae). Evolution, 45, 780-784.

WRight, s. 1951. The genetic structure of populations. Ann. Eugen., 15, 323-354. 